Research article

\title{
ERalpha-status of disseminated tumour cells in bone marrow of primary breast cancer patients
}

\author{
Tanja Fehm ${ }^{1}$, Natalia Krawczyk ${ }^{1}$, Erich-Franz Solomayer ${ }^{1}$, Graziella Becker-Pergola1 , Silke Dürr- \\ Störzer ${ }^{1}$, Hans Neubauer ${ }^{1}$, Harald Seeger ${ }^{1}$, Annette Staebler ${ }^{2}$, Diethelm Wallwiener ${ }^{1}$ and \\ Sven Becker ${ }^{1}$
}

\author{
1Department of Obstetrics and Gynecology, University of Tuebingen, Calwerstrasse 7, D-72076 Tuebingen, Germany \\ 2Department of Pathology, University of Tuebingen, Liebermeisterstrasse 8, D-72076 Tuebingen, Germany \\ Corresponding author: Tanja Fehm, tanja.fehm@t-online.de
}

Received: 1 Jul 2008 Revisions requested: 14 Aug 2008 Revisions received: 11 Sep 2008 Accepted: 15 Sep 2008 Published: 15 Sep 2008

Breast Cancer Research 2008, 10:R76 (doi:10.1186/bcr2143)

This article is online at: http://breast-cancer-research.com/content/10/5/R76

(c) 2008 Fehm et al.; licensee BioMed Central Ltd.

This is an open access article distributed under the terms of the Creative Commons Attribution License (http://creativecommons.org/licenses/by/2.0), which permits unrestricted use, distribution, and reproduction in any medium, provided the original work is properly cited.

\begin{abstract}
Introduction Isolated disseminated tumour cells (DTC) are regarded as surrogate markers for minimal residual disease in breast cancer. Characterisation of these cells could help understand the known limitations of adjuvant therapy. Of particular interest is their oestrogen-receptor (ER) status because endocrine adjuvant therapy remains a cornerstone of breast cancer treatment.
\end{abstract}

Methods Bone marrow (BM) aspirates from 254 patients with primary breast cancer were included in this study. A double immunofluorescence staining procedure was established for the identification of cytokeratin (CK) positive/Er $\alpha$-positive cells. ER $\alpha$ status of the primary tumour was assessed immunohistochemically using the same antibody against ER $\alpha$.

Results In 107 of 254 (42\%) breast cancer patients, CKpositive cells could be detected in the BM. More than one DTC in the BM was observed in 38 of the 107 patients. The number of detected cells ranged between 1 and 55 cells per $2 \times 10^{6}$ mononuclear cells. DTCs demonstrated ER $\alpha$ positivity in $12 \%$ of the patients. The ER $\alpha$ expression was heterogeneous in 10 of the $38(26 \%)$ patients with more than one DTC. The concordance rate of $\mathrm{ER} \alpha$ status between primary tumour and DTC was $28 \%$. Only 12 of 88 patients with ER $\alpha$-positive tumours also had ER $\alpha$-positive DTCs.

Conclusions Primary tumours and DTCs displayed a concordant ER $\alpha$ status in only $28 \%$ of cases. Most of the DTCs were ER $\alpha$ negative despite the presence of an ER $\alpha$-positive primary tumour. These findings further underline the distinct nature of DTCs and may explain the failure rates seen in conventional endocrine adjuvant therapy.

\section{Introduction}

Tumour cell dissemination is a common phenomenon in breast cancer where isolated disseminated cells can be detected in up to $40 \%$ of patients at the time of primary diagnosis [1-3]. Based on the pooled analysis of the bone marrow (BM) micrometastasis group, disseminated tumour cells (DTC) are a surrogate marker of minimal residual disease. Their presence is associated with a poor prognosis [4]. With their prognostic significance clearly demonstrated, efforts have been made to further characterise these cells using pheno- and genotyping techniques. Studies have shown that the persistence of DTCs in the BM of patients with primary breast cancer after conventional adjuvant therapy is associated with a poor prognosis [57].

More detailed knowledge about their cellular and molecular characteristics could help define a targeted secondary adjuvant therapy in patients with primary breast cancer who have undergone conventional adjuvant therapy. It has already been shown that about $40 \%$ of DTCs express human epidermal growth factor receptor 2 (HER2) and that in some patients with recurrent breast cancer their HER2 status may differ from 
that of the primary tumour [8]. Since the most widely used form of targeted therapy for breast cancer remains anti-oestrogen endocrine therapy, it is important to know if the ER $\alpha$ status of DTCs corresponds to the ER $\alpha$ status of the primary tumour, particularly in view of the 15 to $20 \%$ relapse rate in early stage ER $\alpha$-positive tumours despite adjuvant endocrine therapy [9]. Furthermore, while ER $\alpha$-negative tumours are not considered candidates for endocrine therapy, the ER $\alpha$ status of DTCs may differ from the primary tumour. The goal of this study was to determine the ER $\alpha$ status of DTCs in BM of breast cancer patients, and to compare the ER $\alpha$ status of DTCs and the corresponding primary tumours.

\section{Materials and methods Collection and analysis of bone marrow}

Prior to any therapy, between 10 and $20 \mathrm{ml}$ of bone marrow were aspirated from the anterior iliac crest of 254 primary breast cancer patients undergoing surgical treatment from 2005 to 2007 at the Department of Gynecology and Obstetrics, University Hospital Tuebingen, Germany.

The characteristics of the patients are shown in Table 1. All specimens were obtained after written informed consent was given and were collected using protocols approved by the institutional review board (114/2006A). Tumour cell isolation and detection was performed based on the recommendations for standardised tumour cell detection [10]. BM samples were separated by density centrifugation over Ficoll with a density of $1.077 \mathrm{~g} / \mathrm{ml}$ (Biochrom, Germany). If necessary red blood cells were lysed with lysis buffer $\left(155 \mathrm{mM} \mathrm{NH}_{4} \mathrm{Cl}, 10 \mathrm{mM}\right.$ $\mathrm{KHCO}_{3}, 0.1 \mathrm{mM}$ EDTA pH 7.2). Using a cytocentrifuge (Hettich, Tuttlingen, Germany), $10^{6}$ mononuclear cells were spun onto a glass slide. The slides were air-dried overnight at room temperature. For detection and characterisation of DTCs, slides were fixed in a $0.5 \%$ neutral buffered formalin solution for 10 minutes. Control cytospins with ER $\alpha$-positive MCF-7 cells were prepared, stored and fixed in the same way to ensure that $E R \alpha$ negativity of a patient's sample was not due to a handling error. Two slides per patient was analysed for the presence of DTCs $\left(2 \times 10^{6}\right.$ cells per patient).

\section{Optimising the ER $\alpha$ staining protocol}

For establishing the $\mathrm{ER} \alpha$ staining procedure, preparations of breast cancer cell lines MCF-7 and SKBR3 mixed with either $\mathrm{BM}$ or peripheral blood mononuclear cells (PBMCs) from a healthy volunteer were used (Figure 1). To optimise the staining procedure, all relevant parameters of the protocol were evaluated as follows: types of primary ER $\alpha$ antibodies used were monoclonal mouse antibodies (NCL-L-ER-6F11, Novocastra Laboratories, UK), polyclonal rabbit antibodies $(\mathrm{H}-184$, Santa Cruz Biotechnology, Inc., CA) and monoclonal rabbit antibodies (SP1, Lab Vision, CA); antibody dilutions used were 1:200, 1:100, 1:50 and 1:25 made with DAKO Antibody Diluent (1\% BSA in PBS, 0.1\% Tween 20); incubation times for primary and secondary antibodies were 30,45 and 60 min-
Table 1

Clinical data of patients

\begin{tabular}{|c|c|c|c|}
\hline & $\mathrm{n}=254$ & BM positive (\%) & $\mathrm{p}$-value \\
\hline Total & 254 & $107(42)$ & \\
\hline \multicolumn{4}{|l|}{ Menopausal status } \\
\hline Premenopausal & 79 & $33(42)$ & 0.94 \\
\hline Postmenopausal & 175 & $74(42)$ & \\
\hline \multicolumn{4}{|l|}{ Tumour size } \\
\hline $\mathrm{pT} 1$ & 148 & $60(41)$ & 0.77 \\
\hline pT2-4 & 103 & $46(45)$ & \\
\hline \multicolumn{4}{|l|}{ Nodal status } \\
\hline Node negative & 149 & $62(42)$ & 0.88 \\
\hline Node positive & 101 & $43(43)$ & \\
\hline \multicolumn{4}{|l|}{ Histology } \\
\hline Ductal & 177 & $74(42)$ & 0.12 \\
\hline Lobular & 57 & $21(37)$ & \\
\hline Others & 17 & $11(65)$ & \\
\hline \multicolumn{4}{|l|}{ Grading } \\
\hline I to II & 217 & $91(42)$ & 0.85 \\
\hline III & 32 & $14(44)$ & \\
\hline \multicolumn{4}{|l|}{ ER status } \\
\hline Negative & 42 & $19(45)$ & 0.83 \\
\hline Positive & 208 & $88(42)$ & \\
\hline \multicolumn{4}{|l|}{ PR status } \\
\hline Negative & 69 & $26(38)$ & 0.39 \\
\hline Positive & 181 & $79(44)$ & \\
\hline \multicolumn{4}{|l|}{ HER2 } \\
\hline Negative $(0 /+1)$ & 211 & $94(45)$ & 0.08 \\
\hline Positive $(+2 /+3)$ & 32 & $9(28)$ & \\
\hline
\end{tabular}

* by Chi-squared test. $\mathrm{BM}=$ bone marrow; $\mathrm{ER}=$ oestrogen receptor; $\mathrm{HER} 2=$ human epidermal growth factor receptor $2 ; \mathrm{PR}=$ progesterone receptor.

utes; selection of secondary antibodies was with Tex-Red labelled horse anti-mouse AB (Vector Laboratories, Inc., CA), Tex-red labelled goat anti-rabbit AB (CB 11, Biogenex, CA) and Alexa Fluor 594 labelled goat anti rabbit $A B$ (Molecular Probes, Invitrogen, CA); cell fixation was 10 minutes of acetone at $4^{\circ} \mathrm{C}, 100 \%$ ethanol for 10 minutes or $0.5 \%$ neutral buffered formalin solution for 10 minutes, all three fixations at room temperature. The optimal ER $\alpha$ staining (low background, strong nuclear staining, no cytoplasmic staining) was determined to be as indicated below. 
Figure 1
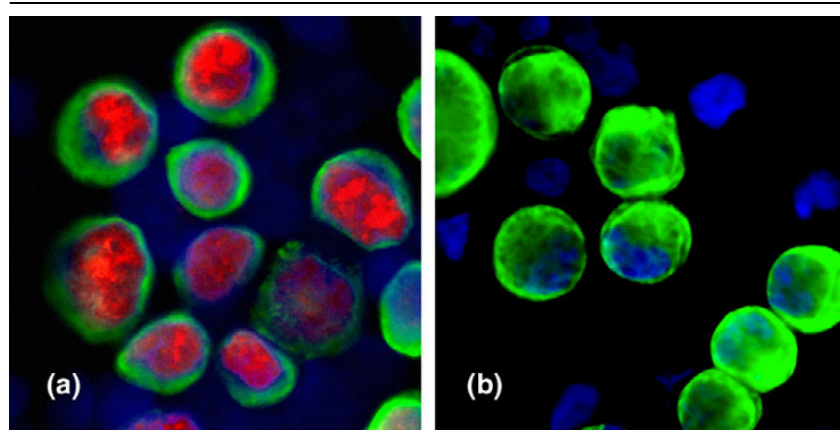

Oestogen receptor (ER) $\alpha$ staining of MCF-7 (positive control) and SKBR3 (negative control) breast cancer cells spiked in bone marrow. A: MCF-7 cancer cells as positive control for ER $\alpha$-staining. B: SKBR3 cancer cells as negative control ER $\alpha$-staining.

\section{Immunofluorescence staining of ER $\alpha$-receptor}

After an initial washing step with PBS (Sigma, Munich, Germany), cells were blocked for 30 minutes with normal goat serum (Dako, Glostrup, Denmark) at a 1:10 dilution. The automated double immunofluorescence staining procedure was performed on the DAKO Autostainer using the monoclonal rabbit ER $\alpha$-antibody SP1 (dilution 1:25, Lab Vision, Fremont, $\mathrm{CA}$, USA) for 60 minutes and secondary detection with a goat anti-rabbit antibody, labelled with Alexa Fluor 594 (1:100, Invitrogen Molecular Probes, Carlsbad, CA, USA) for 30 minutes. Cytospins were then incubated with a pan-cytokeratin (CK) antibody (C11) directly conjugated to fluorescein isothiocyanate (FITC) (1:100, Sigma, Munich, Germany) for 30 minutes. This monoclonal antibody recognises human CKs 4, 5, 6, $8,10,13$ and 18 . Counterstaining was performed with 4'6-diamidino-2-phenylindole (DAPI) in mounting media (Vector Laboratories, Burlingame, CA, USA). Preparations of the breast cancer cell line MCF-7 mixed with PBMCs from a healthy volunteer served as a positive control for $\mathrm{CK}$ and ER $\alpha$ staining. ER $\alpha$ negative control slides of SKBR-3/PBMC mixtures were also included with each batch of samples. Cytospins of PBMCs with no added tumour cells served as a negative control for both.

\section{Fluorescence microscopy}

Slides were manually analysed for the presence of tumour cells using a computerised fluorescence microscope Axiophot ( $\times 40$ oil immersion objectives, Carl Zeiss Micro Imaging $\mathrm{GmbH}$, Göttingen, Germany). To screen for ER $\alpha$-positive tumour cells, a single-pass filter for individual fluorochromes, FITC, Texas Red or DAPI, and a dual-pass filter for FITC/Texas Red were used. Criteria for evaluation of immunostained cells were based on the criteria of the International Society of Hematotherapy and Graft Engineering Working group for standardisation of tumour cell detection and the consensus statements $[10,11]$. Criteria for ER $\alpha$ positivity were either moderate or intense staining of the entire nucleus. Slides were evaluated by two, or in doubtful cases three, independent investigators (TF, NK and ES).

\section{Immunohistochemical staining of the primary tumour}

Immunohistochemical analysis was performed either on core biopsies or surgical resection specimens. The tissue was fixed in $4.5 \%$ buffered formalin $(\mathrm{pH} \mathrm{7.0)}$ and embedded in paraffin. Immunohistochemical staining was performed on 3 to $5 \mu \mathrm{m}$ thick sections using a commercially available $A B C$ kit (Vectastain, Vector Laboratories, Burlingame, CA, USA). The $\mathrm{ER} \alpha$ antibody (clone SP1) was diluted 1:200 in Tris- $\mathrm{HCl}(\mathrm{pH}$ 7.5) and applied according to the manufacturer's instruction (DCS, Hamburg, Germany). 3,3'diaminobenzidine (DAB) was used as a chromogen. Finally, the slides were counterstained with haematoxylin and mounted for examination. For assessment of the ER $\alpha$ status, the percentage of cells with nuclear reactivity (score 0: none, 1: > 10\%, 2: 10 to $50 \%, 3: 51$ to $80 \%, 4:>80 \%$ ) and the intensity of ER staining (score 0: none, 1: weak, 2: moderate, 3: strong) was determined. ER $\alpha$ expression was scored semi-quantitatively using the Remmele-score (score nuclear staining $\times$ score intensity of ER staining). Tumours with a score of 2 or more were considered ER $\alpha$ positive.

\section{Statistical analysis}

A chi-squared test or Fisher's exact test was used to evaluate the relation between ER $\alpha$-positive DTCs and clinicopathological factors. Statistical analysis was performed by SPSS, version 11.5 (SPSS Inc., Chicago, IL, USA). $p<0.05$ was considered statistically significant.

\section{Results}

\section{Patients' charateristics}

A total of 254 patients were included in the study. Clinical data are shown in detail in Table 1. Of patients, $82 \%$ had ER $\alpha$-positive primary tumours and DTCs were observed in $107(42 \%)$ of them. Figure 2 shows the cytomorphology and immunophenotype of a representative DTC of a patient with breast cancer. As can be seen, the nuclear to cytoplasmic ratio is high, the

\section{Figure 2}

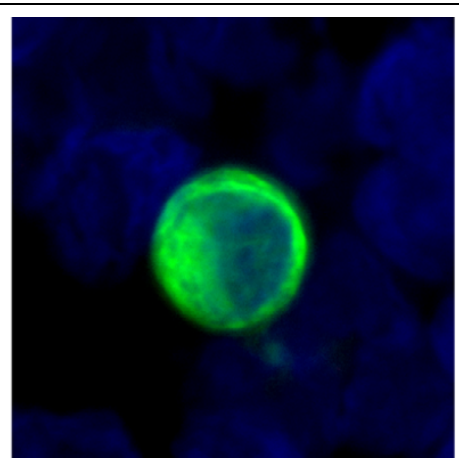

Typical cytomorphology (nuclear size clearly enlarged, high nuclear to cytoplasmic ratio) and immunophenotype (irregular cytoplasmic staining for cytokeratin, cytokeratin filaments can be seen) of a representative disseminated tumour cell from a breast cancer patient. The tumour cell is stained with an anti-cytokeratin-fluorescein isothiocyanate (green) ( $\times 40$ oil immersion objective). 
Table 2

Correlation between ER $\alpha$ status of primary tumour and disseminated tumour cells

\begin{tabular}{|c|c|c|c|c|}
\hline & \multirow[t]{2}{*}{ ER $\alpha$ status } & \multicolumn{2}{|c|}{ DTC } & \multirow[t]{2}{*}{ Total (\%) } \\
\hline & & ER $\alpha$ negative (\%) & ER $\alpha$ positive (\%) & \\
\hline \multirow[t]{3}{*}{ Tumour } & ER $\alpha$ negative (\%) & $18(17)$ & $1(1)$ & $19(18)$ \\
\hline & ER $\alpha$ positive (\%) & $76(71)$ & $12(11)$ & $88(82)$ \\
\hline & Total (\%) & $94(88)$ & $13(12)$ & $107(100)^{*}$ \\
\hline
\end{tabular}

${ }^{\star} p=0.8$ (chi-squared-test). ER $=$ oestrogen receptor; $\mathrm{DTC}=$ disseminated tumour cells.

nucleus has irregularities and the CK stains the cytoplasm at the periphery of the cell causing a ring-like appearance. These are all accepted morphological criteria for malignant cells. The number of DTCs ranged from 1 to 55 cells/patient $\left(2 \times 10^{6}\right.$ mononuclear cells). In 38 of the 107 (35\%) BM-positive patients, more than one DTC could be detected. No correlation was observed between positive BM status and any of the established prognostic markers including the ER $\alpha$ status of the primary tumour (Table 1).

\section{ER $\alpha$ expression in disseminated tumour cells}

ER $\alpha$ status of DTCs was simultaneously evaluated using a double immunofluorescence staining procedure. The majority of patients (88\%) had ER $\alpha$-negative tumour cells in BM (Table 2). ER $\alpha$-positive tumour cells could only be detected in 13 of 107 (12\%) patients with BM involvement. ER $\alpha$-positive but $\mathrm{CK}$-negative cells were not observed. Figure 3 shows ER $\alpha$ positive tumour cells from different patients. As can be seen, the nuclei are strongly stained with the ER antibody.

Of the 107 patients, 38 had more than one DTC in the BM. Of

Figure 3
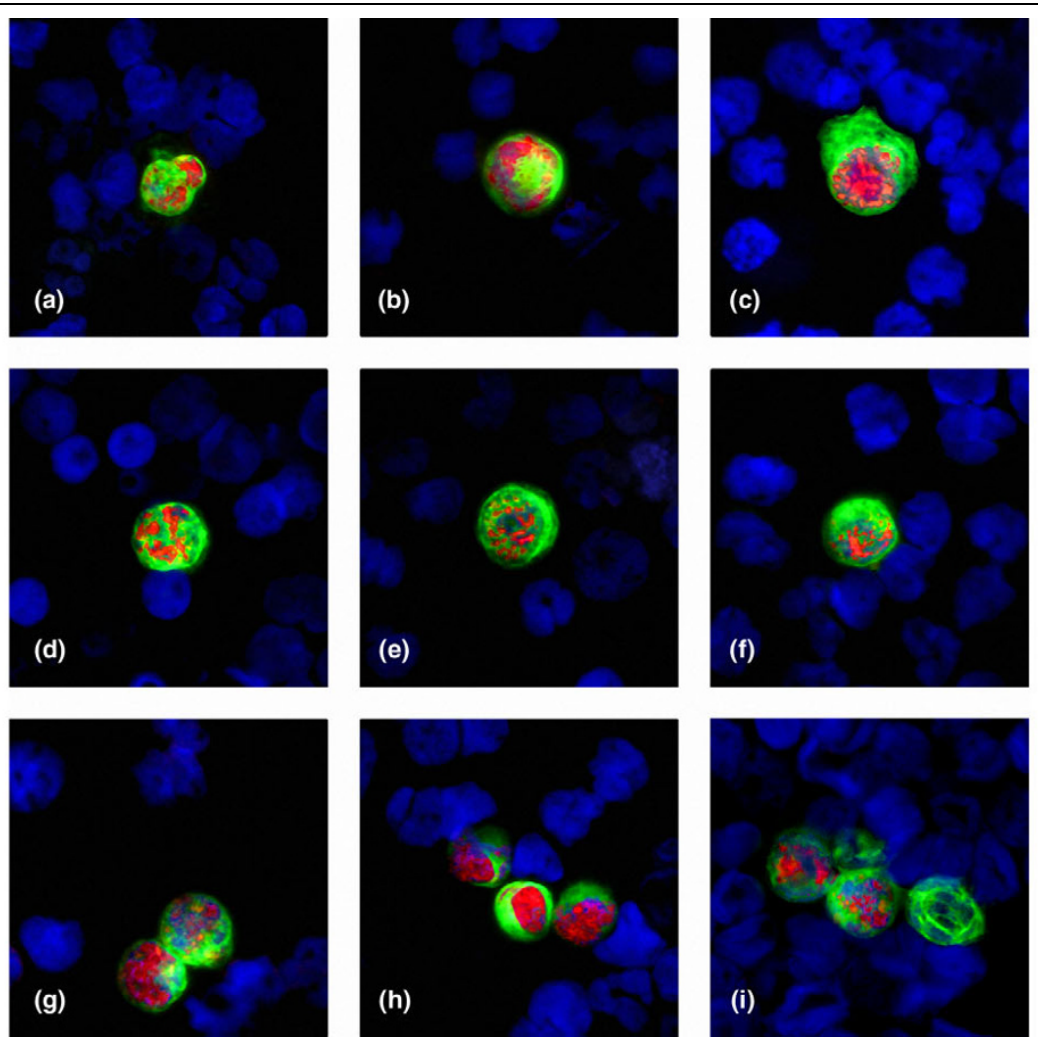

Immunophenotyping of disseminated tumour cells from patients with primary breast cancer. The tumour cells were stained with an anti-cytokeratinfluorescein isothiocyanate (green) and anti-oestrogen receptor (ER) $\alpha$ detected by a secondary Alexa Fluor 594 labelled goat anti-rabbit antibody (red). Nuclei are stained blue with 4'6-diamidino-2-phenylindole (DAPI) ( $\times 40$ oil immersion objective). A-F: Breast cancer patients with ER $\alpha$-positive disseminated tumour cells. G-H: Clusters of ER $\alpha$-positive disseminated tumour cells. I: Cluster of ER $\alpha$-positive and ER $\alpha$-negative tumour cells. 
Correlation between ER $\alpha$ status of primary tumour and heterogeneity of ER $\alpha$ expression in patients with more than one disseminated tumour cell (DTC).

\begin{tabular}{llcccc}
\hline \multirow{2}{*}{ ER $\alpha$ status } & \multicolumn{2}{c}{ DTC } & Total (\%) \\
\cline { 3 - 5 } & & $\mathrm{ER} \alpha+(\%)$ & $\mathrm{ER} \alpha-(\%)$ & $\mathrm{ER} \alpha+(\%) \&-(\%)$ & $7(18)$ \\
\hline Tumour & $\mathrm{ER} \alpha-(\%)$ & 0 & $7(18)$ & $10(26)$ & $31(82)$ \\
\hline & $\mathrm{ER} \alpha+(\%)$ & 0 & $21(55)$ & $10(26)$ & $38(100)$ \\
\hline
\end{tabular}

${ }^{\star} p=0.3$ (Fisher-exact-test, two-sided). ER = oestrogen receptor.; $+=$ positive; - = negative.

these 38 patients, 28 had only ER $\alpha$-negative tumour cells (Table 3). Heterogeneity of ER $\alpha$ expression could be detected in the remaining $10(26 \%)$ patients (Figure 3i).

\section{Comparison of ER $\alpha$ expression between primary tumour and disseminated tumour cells}

The ER $\alpha$ status of the primary tumour could be determined in all 107 patients with detectable DTCs in the BM. ER $\alpha$ positivity of the primary tumour was demonstrated in $88(82 \%)$ of these patients. The concordance rate between ER $\alpha$ status of DTCs and primary tumour was $28 \%$. Only 12 of the $88(14 \%)$ patients with ER $\alpha$-positive primary tumour had ER $\alpha$-positive DTCs in the BM. In contrast, 18 of 19 (95\%) patients with ER $\alpha$-negative primary tumours also had ER $\alpha$-negative DTCs (Table 2). The extent of ER $\alpha$ expression (negative, low, moderate or strong) of the primary tumour was not correlated to the $\mathrm{ER} \alpha$ status of DTCs. The comparison of ER $\alpha$ expression between primary tumours and DTCs is summarised in Tables 2 and 3.

\section{Discussion}

Evaluation of ER $\alpha$ status of the primary tumour by immunohistochemistry has been part of routine clinical practice for many years and currently determines patient eligibility for adjuvant endocrine therapy. The assumption is that DTCs will share most characteristics with the primary tumour.

However, an increasing number of publications indicate a more complex relation between the primary tumour and DTCs, with considerable discrepancies noted the genomic level $[12,13]$. Supporting this evidence at the phenotypic level are studies looking at HER2 status differences between primary tumours and isolated DTCs $[8,14,15]$.

Similarly, the ER $\alpha$ status of DTCs could be completely different to that of the primary tumour which on the one hand (ER $\alpha$ negative primary tumour, ER $\alpha$-positive DTCs) could increase the number of patients eligible for endocrine therapy and on the other hand (ER $\alpha$-positive primary tumour, ER $\alpha$-negative DTCs) could explain why endocrine therapy fails in a subset of hormone receptor-positive patients.
Looking at a large patient group, our data confirms findings of previous, smaller studies, indicating that the ER $\alpha$ status of the primary tumour does not necessarily reflect the ER $\alpha$ status of minimal residual disease (Table 4). In an observational study looking at 17 primary tumours and their corresponding DTCs, Ditsch et al. found that only two of 11 patients with ER $\alpha$-positive primary tumours (18\%) had ER $\alpha$-positive DTCs [16]. Reuben et al. investigated the ER $\alpha$ status of circulating tumour cells in metastatic breast cancer patients and their corresponding primary tumours: fourteen of 16 patients $(88 \%)$ had ER $\alpha$-positive primary tumours, but only three patients had ER $\alpha$-positive circulating tumour cells [17]. Our results confirm the conclusions that DTCs do not reflect the ER $\alpha$ status of the corresponding primary tumour and a majority of DTCs tend to be $E R \alpha$ negative.

As mentioned above, these discrepancies between DTCs and the primary tumour are not confined to ER $\alpha$-expression: Solomayer et al. compared the HER2 status of DTC and primary tumour in 137 cases [8] and found that DTCs were more likely to express HER2 than the primary tumour. Meng et al. reported HER2-positive circulating tumour cells in nine of 24 (38\%) patients with recurrent breast cancer who had HER2-negative tumours [15]. It has been suggested that the high rate of HER2-positive DTCs reflects on their potentially more aggressive phenotype. Other studies looking at markers such as major histocompatibility complex (MHC) III and Ki-76 have reported similar discrepancies $[18,19]$.

Different hypotheses need to be discussed with regard to our findings. One possible explanation is the clonal heterogeneity of the primary tumour: ER $\alpha$-negative cells could be more likely to disseminate, corresponding to the worse prognosis of predominantly ER $\alpha$ negative tumours and - inversely - to the demonstrated decreased invasiveness and metastatic potential of ER $\alpha$-expressing breast cancer cells [20,21]. MCF-7 cells, established from a pleural effusion, express ER $\alpha$ and are oestrogen-responsive breast cancer cells. MCF-7 cells do not form metastases in nude mice unless oestrogen supplementation is provided [22-24]. MDA-MB-231 cells were also established from a pleural effusion; however, these cells are ER $\alpha$ negative and highly invasive. Intravenous injection of MDA- 
Table 4

Comparison of ER $\alpha$ status of the primary tumour and metastatic lesion $\S$

\begin{tabular}{|c|c|c|c|c|c|c|}
\hline Author & $N$ & $\begin{array}{c}\text { Primary tumour ER }+ \\
\%\end{array}$ & $\begin{array}{l}\text { ER discordance rate } \\
(\%)\end{array}$ & Site of metastasis & $\begin{array}{c}\text { Change ER+/ER- N } \\
(\%)\end{array}$ & $\begin{array}{c}\text { Change ER-/ER+ N } \\
(\%)\end{array}$ \\
\hline Nomura et al. [35] & 42 & 64 & $10(24)$ & LR & $10(24)$ & 0 \\
\hline Kuukasjarvi et al. [25] & 50 & 70 & $12(24)$ & LR, MET & $12(24)$ & 0 \\
\hline Lower et al. [36] & 200 & 58 & $60(30)$ & MET & $39(20)$ & $21(11)$ \\
\hline Li et al. [37] & 83 & 76 & $24(29)$ & LR, MET & $83(16)$ & $11(13)$ \\
\hline Fernandez et al. [27] & 26 & 65 & (35) & LN & $6(23)$ & 0 \\
\hline $\begin{array}{l}\text { Raemaekers et al. } \\
\text { [38] }\end{array}$ & 75 & 58 & $14(19)$ & LR, LN & $8(10)$ & $6(8)$ \\
\hline Zheng et al. [26] & 52 & 54 & (10) & LN & $3(10)$ & 0 \\
\hline Ditsch et al. [16] & 17 & 64 & $9(53)$ & DTC & $9(53)$ & 0 \\
\hline Broom et al. [28] & 62 & 18 & $11(18)$ & DTC, LN, MET & $6(10)$ & $5(8)$ \\
\hline Our study & 107 & 82 & 77 (82) & BM & $76(71)$ & $1(1)$ \\
\hline
\end{tabular}

§distant metastasis, local recurrence, lymph nodes

$\mathrm{BM}=$ bone marrow; $\mathrm{DTC}=$ disseminated tumour cells; $\mathrm{LN}=$ lymph nodes; $\mathrm{LR}=$ local recurrence; $\mathrm{MET}=$ metastatic lesion.

MB-231 cells into the tail vein of nude mice produces tumours [24]. Furthermore, it is well known that about 20 to $30 \%$ of patients with ER $\alpha$-positive primary tumours develop ER $\alpha$-negative metastatic diseases [25-28].

One interesting hypothesis currently under discussion is the theory that some or all DTCs, the presumed precursor cells of systemic metastatic disease, are in fact cancer stem cells. As recently published, this theory states that tumour growth and formation of secondary tumours can be traced to a small subpopulation of tumour cells, so called cancer stem cells $[29,30]$. First, most DTCs do not respond to cytotoxic therapy because they are not proliferating and persist over many years in BM. This is also true for tumour stem cells. Secondly, it was also demonstrated that most DTCs in BM were CD44 positive and CD24 low/negative [31]. The CD44-/CD 24-/low phenotype represents a minor population within primary tumours that is associated with self-renewal and tumourigenic potential. In addition, it has been shown that the CD44+/CD24- phenotypes correlated with a higher prevalence of metastases [32]. As breast cancer stem cells have been shown to be generally ER $\alpha$ negative, DTCs with an ER $\alpha$-negative phenotype despite an $\mathrm{ER} \alpha$-positive primary tumour would agree with the cancer stem cell theory [33,34].

\section{Conclusion}

The phenotypic discrepancies between DTCs and their corresponding primary tumours have the potential to increase our understanding of why treatments are successful in some, but not in other patients, paving the way towards more individualised forms of treatment. The target of adjuvant therapy is the eradication of minimal residual disease. In order to optimise treatment strategies, the phenotypic properties of DTCs - the surrogate marker of minimal residual disease - should be taken into account in addition to characterisation of the primary tumour. Already, the available studies looking at phenotypic properties of DTCs have often found them to be nonproliferative, ER $\alpha$ negative and HER2 positive $[8,16,28]$. For these patients, expanded treatment with HER2-specific therapies (e.g. trastuzumab and lapatinib) could prove especially beneficial. To further clarify these questions, the next step should be a more generalised and systematic characterisation of DTC-status before and after standard adjuvant therapy for all patients.

\section{Competing interests}

The authors declare that they have no competing interests.

\section{Authors' contributions}

TF, GPB, SD, NK, AS and ES made substantial contributions to the conception and design of the study, acquisition of data, and analysis and interpretation of data. TF, SB, HS and HN were involved in drafting the manuscript or revising it. All authors read and approved the final manuscript.

\section{Acknowledgements}

We would like to thank Dr Jonathan Uhr and Nancy Lane (UT Southwestern Medical School, Dallas, USA) for reviewing the manuscript. This work was supported by the IZKF-grant (1686-0-0) of the University of Tuebingen.

\section{References}

1. Diel IJ, Kaufmann M, Costa SD, Holle R, von Minckwitz G, Solomayer EF, Kaul S, Bastert G: Micrometastatic breast cancer cells in bone marrow at primary surgery: prognostic value in comparison with nodal status. J Natl Cancer Inst 1996, 88:1652-1658.

2. Solomayer EF, Diel IJ, Salanti G, Hahn M, Gollan C, Schütz F, Bastert G: Time independence of the prognostic impact of tumor cell detection in the bone marrow of primary breast cancer patients. Clin Cancer Res 2001, 7:4102-4108. 
3. Braun S, Pantel K, Müller P, Janni W, Hepp F, Kentenich CR, Gastroph S, Wischnik A, Dimpfl T, Kindermann G, Riethmüller G, Schlimok G: Cytokeratin-positive cells in the bone marrow and survival of patients with stage I, II, or III breast cancer. $N$ Engl $J$ Med 2000, 342:525-533.

4. Braun S, Vogl FD, Naume B, Janni W, Osborne MP, Coombes RC, Schlimok G, Diel IJ, Gerber B, Gebauer G, Pierga JY, Marth C, Oruzio D, Wiedswang G, Solomayer EF, Kundt G, Strobl B, Fehm T, Wong GY, Bliss J, Vincent-Salomon A, Pantel K: A pooled analysis of bone marrow micrometastasis in breast cancer. N Engl J Med 2005, 353:793-802.

5. Wiedswang G, Borgen E, Kåresen R, Qvist $H$, Janbu J, Kvalheim G, Nesland JM, Naume B: Isolated tumor cells in bone marrow three years after diagnosis in disease-free breast cancer patients predict unfavorable clinical outcome. Clin Cancer Res 2004, 10:5342-5348.

6. Braun S, Kentenich C, Janni W, Hepp F, de Waal J, Willgeroth F, Sommer $\mathrm{H}$, Pantel K: Lack of effect of adjuvant chemotherapy on the elimination of single dormant tumor cells in bone marrow of high-risk breast cancer patients. J Clin Oncol 2000, 18:80-86.

7. Becker S, Becker-Pergola G, Wallwiener D, Solomayer EF, Fehm $\mathrm{T}$ : Detection of cytokeratin-positive cells in the bone marrow of breast cancer patients undergoing adjuvant therapy. Breast Cancer Res Treat 2006, 97:91-96.

8. Solomayer EF, Becker S, Pergola-Becker G, Bachmann R, Krämer $B$, Vogel U, Neubauer H, Wallwiener D, Huober J, Fehm TN: Comparison of HER2 status between primary tumor and disseminated tumor cells in primary breast cancer patients. Breast Cancer Res Treat 2006, 98:179-184.

9. Breast International Group (BIG) 1-98 Collaborative Group, Thürlimann B, Keshaviah A, Coates AS, Mouridsen H, Mauriac L, Forbes JF, Paridaens R, Castiglione-Gertsch M, Gelber RD, Rabaglio M, Smith I, Wardley A, Price KN, Goldhirsch A: A comparison of letrozole and tamoxifen in postmenopausal women with early breast cancer. N Engl J Med 2005, 353:2747-2757.

10. Fehm T, Braun S, Muller V, Janni W, Gebauer G, Marth C, Schindlbeck $\mathrm{C}$, Wallwiener D, Borgen E, Naume B, Pantel K, Solomayer $\mathrm{E}: \mathrm{A}$ concept for the standardized detection of disseminated tumor cells in bone marrow from patients with primary breast cancer and its clinical implementation. Cancer 2006, 107:885-892.

11. Borgen E, Naume B, Nesland JM, Kvalheim G, Beiske K, Fodstad O, Diel I, Solomayer EF, Theocharous P, Coombes RC, Smith BM, Wunder E, Marolleau JP, Garcia J, Pantel K: Standardization of the immunocytochemical detection of cancer cells in BM and blood. I. Establishment of objective criteria for the evaluation of immunostained cells. Cytotherapy 1999, 5:377-388.

12. Schmidt-Kittler O, Ragg T, Daskalakis A, Granzow M, Ahr A, Blankenstein TJ, Kaufmann M, Diebold J, Arnholdt H, Muller P, Bischoff J, Harich D, Schlimok G, Riethmuller G, Eils R, Klein CA: From latent disseminated cells to overt metastasis: genetic analysis of systemic breast cancer progression. Proc Natl Acad Sci USA 2003, 100:7737-7742.

13. Klein CA, Blankenstein TJ, Schmidt-Kittler O, Petronio M, Polzer B, Stoecklein NH, Riethmüller G: Genetic heterogeneity of single disseminated tumour cells in minimal residual cancer. Lancet 2002, 360:683-639.

14. Becker S, Becker-Pergola G, Fehm T, Wallwiener D, Solomayer EF: Her2 expression on disseminated tumor cells from bone marrow of breast cancer patients. Anticancer Res 2005, 25:2171-2175.

15. Klein CA, Blankenstein TJ, Schmidt-Kittler O, Petronio M, Polzer B, Stoecklein NH, Riethmüller G: UPAR and HER-2 gene status in individual breast cancer cells from blood and tissues. Proc Natl Acad Sci USA 2006, 103:17361-17365.

16. Ditsch N, Mayer B, Rolle M, Untch M, Schildberg FW, Funke I: Estrogen receptor expression profile of disseminated epithelial tumor cells in bone marrow of breast cancer patients. Recent Results Cancer Res 2003, 162:141-147.

17. Reuben JMLB, Li C, Broglio KR, Valero V, Jackson S, Ueno NT, Krishnamurthy S, Hortobagyi GN, Cristofanilli M: Genomic of circulating tumor cells in metastatic breast cancer. J Clin Oncol (Meeting Abstracts) 2007, 25:1002.

18. Pantel K, Schlimok G, Braun S, Kutter D, Lindemann F, Schaller G, Funke I, Izbicki JR, Riethmüller G: Differential expression of pro- liferation-associated molecules in individual micrometastatic carcinoma cells. J Natl Cancer Inst 1993, 85:1419-1424.

19. Pantel K, Schlimok G, Kutter D, Schaller G, Genz T, Wiebecke B, Backmann R, Funke I, Riethmüller G: Frequent down-regulation of major histocompatibility class I antigen expression on individual micrometastatic carcinoma cells. Cancer Res 1991, $51: 4712-4715$

20. Thompson EW, Paik S, Brünner N, Sommers CL, Zugmaier G, Clarke R, Shima TB, Torri J, Donahue S, Lippman ME, Martin GR, Dickson RB: Association of increased basement membrane invasiveness with absence of estrogen receptor and expression of vimentin in human breast cancer cell lines. J Cell Physiol 1992, 150:534-544.

21. Platet N, Prevostel C, Derocq D, Joubert D, Rochefort H, Garcia $M$ : Breast cancer cell invasiveness: correlation with protein kinase $\mathbf{C}$ activity and differential regulation by phorbol ester in estrogen receptor-positive and -negative cells. Int J Cancer 1998, 75:750-756

22. Price JE, Polyzos A, Zhang RD, Daniels LM: Tumorigenicity and metastasis of human breast carcinoma cell lines in nude mice. Cancer Res 1990, 50:717-721.

23. Mukhopadhyay R, Theriault RL, Price JE: Increased levels of alpha6 integrins are associated with the metastatic phenotype of human breast cancer cells. Clin Exp Metastasis 1999, 17:325-332.

24. Shafie SM, Liotta LA: Formation of metastasis by human breast carcinoma cells (MCF-7) in nude mice. Cancer Lett 1980, 11:81-87.

25. Kuukasjarvi T, Kononen J, Helin H, Holli K, Isola J: Loss of estrogen receptor in recurrent breast cancer is associated with poor response to endocrine therapy. J Clin Oncol 1996 14:2584-2589.

26. Zheng WQ, Lu J, Zheng JM, Hu FX, Ni CR: Variation of ER status between primary and metastatic breast cancer and relationship to p53 expression*. Steroids 2001, 66:905-910.

27. Fernandez D, Sauven $P$, Alaghband-Zadeh J, Burn JI: Variability of oestrogen and progesterone receptor status between primary breast cancer and nodal metastases: preliminary communication. J $R$ Soc Med 1982, 75:719-722.

28. Broom RJ, Tang P, Simmons C, Bordeleau L, O'Malley FP, Miller $\mathrm{N}$, Andrulis IL, Brenner DM, Clemons M: Changes in estrogen receptor (ER), progesterone receptor (PR) and HER2/neu status with time: Discordance rates between primary and metastatic breast pathology samples. Clin Oncol (Meeting Abstracts) 2007, 25:1024.

29. Reya T, Morrison SJ, Clarke MF, Weissman IL: Stem cells, cancer, and cancer stem cells. Nature 2001, 414:105-111.

30. Al-Haij M, Wicha MS, Benito-Hernandez A, Morrison SJ, Clarke MF: Prospective identification of tumorigenic breast cancer cells. Proc Natl Acad Sci USA 2003, 100:3983-3988.

31. Balic M, Lin H, Young L, Hawes D, Giuliano A, McNamara G, Datar $\mathrm{RH}$, Cote RJ: Most early disseminated cancer cells detected in bone marrow of breast cancer patients have a putative breast cancer stem cell phenotype. Clin Cancer Res 2006, 12:5615-5621.

32. Abraham BK, Fritz $P$, McClellan $M$, Hauptvogel $P$, Athelogou $M$, Brauch $\mathrm{H}$ : Prevalence of CD44+/CD24-/low cells in breast cancer may not be associated with clinical outcome but may favor distant metastasis. Clin Cancer Res 2005, 11:1154-1159.

33. Dontu G, El-Ashry D, Wicha MS: Breast cancer, stem/progenitor cells and the estrogen receptor. Trends Endocrinol Metab 2004, 15:193-197.

34. Asselin-Labat ML, Shackleton M, Stingl J, Vaillant F, Forrest NC Eaves CJ, Visvader JE, Lindeman GJ: Steroid hormone receptor status of mouse mammary stem cells. J Nat/ Cancer Inst 2006, 98:1011-1014.

35. Nomura $\mathrm{Y}$, Tashiro $\mathrm{H}$, Shinozuka $\mathrm{K}$ : Changes of steroid hormone receptor content by chemotherapy and/or endocrine therapy in advanced breast cancer. Cancer 1985, 55:546-551.

36. Lower EE, Glass EL, Bradley DA, Blau R, Heffelfinger S: Impact of metastatic estrogen receptor and progesterone receptor status on survival. Breast Cancer Res Treat 2005, 90:65-70.

37. Li BD, Byskosh A, Molteni A, Duda RB: Estrogen and progesterone receptor concordance between primary and recurrent breast cancer. J Surg Oncol 1994, 57:71-77. 
Breast Cancer Research Vol 10 No 5 Fehm et al.

38. Raemaekers JM, Beex LV, Koenders AJ, Pieters GF, Smals AG, Benraad TJ, Kloppenborg PW: Concordance and discordance of estrogen and progesterone receptor content in sequential biopsies of patients with advanced breast cancer: relation to survival. Eur J Cancer Clin Oncol 1984, 20:1011-1018. 